\title{
BUILDING PLURALIST ATTITUDE IN DOING ISLAMIC EDUCATION AT HIGHT SCHOOL AND MADRASAH
}

\author{
Moh. Haitami Salim \\ Graduate School of the Pontianak State College of Islamic Studies
}

\begin{abstract}
The pluralist attitude is often associated with acknowledging and appreciating ethnic and religious differences which are, in fact, plural. The plurality of ethnicity is a natural process because no one can choose to be born into parents of a certain group. Meanwhile the plurality of religion is the result of someone's choice of faith and is part of the human rights. A person cannot change their ethnicity but it is possible for them to change their religion. Nor can religious conversion change a person's ethnicity, as in the case in West Kalimantan where a Christian ethnic Dayak converts to Islam to become a Malay, for example. It is why religion and ethnicity are plural, so appreciating and acknowledging the plurality as inevitability is known as a "pluralist" attitude. In Islam, especially in the instruction of Islamic education at school, or madrasah, pluralist attitude should be extended to include not only the attitude of acknowledging and appreciating ethnic and religious differences, but also the awareness of the existence of variants of the plurality in a religion, ethnicity and even in a family. Building a pluralist attitude among people with the same faith and ethnicity is often overlooked, that later led to an attitude of ambiguity, thus being friendly towards people of a different religion or ethnicity, but being hostile when dealing with fellow religious or ethnic members. The phenomenon is clearly visible in the dispute between the followers of Sunni and the Shi'ite in which the leaders are brothers. To ensure that the instruction of Islamic education is able to build a pluralist attitude on learners, we need to start building the ability of teachers to develop the curriculum, prepare the lesson plans, develop contextual learning materials and use varied learning strategies and methods.
\end{abstract}

Keywords: Instruction of Islamic education, Pluralist attitude, School, Madrasah

\section{INTRODUCTION}

The Indonesian society is known for its rich human and natural resource potential because it has a very high degree of plurality. The plurality of Indonesia can be seen from the various religious beliefs, not only the official religions (recognized by the state) but also other beliefs, and even "other religions" (in the statistical term), as well as various ethnic groups, languages, skin colors, 
cultures and so forth (Moh. Haitami Salim, 2009: 1). It is a reality that we live in the midst of diversity, particularly in Indonesia which is famous for it, ranging from ethnicity, race, national origin, ancestry, religion, language, customs, to the level of education, and social and economic background. As an illustration, Indonesia now has a population of more than 200 million, made up of hundreds and even thousands of ethnic groups and more than 525 languages and dialects spreading along approximately 17,800 small and large islands, stretching 5,150 km between the continents of Asia and Australia, and across the Pacific Indian and Oceans. According to the statistical data collected in 1995, the population of the country based on religion is as follows: Muslims, 87.21\%; Protestants 6.04\%; Catholics, 3.58\%; Hindus, 1.83\%; Buddhists, 1.03\%; and animists 0.31\%. (Moh. Haitami Salim (a), 21: 25).

The diversity of Indonesia is a reality that must be accepted as a gift from Allah Almighty, Most wealthy and Most perfect. It must also be understood as the will of Allah, so that people can get to know each other, compete in virtue and so on.

To understand the plurality, either as a gift from or as the way of Allah Almighty, the children of this nation need good and right insights that should be instilled as early as possible at all levels of education so as to promote a positive attitude toward the plurality of the community. A positive attitude should be able to keep two aspects of interest, that is the faith or belief that should not be sacrificed for the sake of plurality, and the other the plurality itself as a reality of society should not clash with the faith. Therefore, the proper mentoring is needed so that the pluralist attitude will not disregard or sacrifice one of the two aspects of interest.

Effective coaching to build the right pluralist attitude can be done through a formal education process in schools or madrasahs because the process is carried out in a systematic, planned, controlled way, and has adequate supporting facilities. Among the subjects relevant for establishing the pluralist attitude is the Islamic education. This article will talk about understanding the meaning of plurality, the pluralist attitude, the Islamic perspective on plurality and the importance of instilling the pluralist attitudes through the instruction of Islamic education, and the instruments needed to instill such attitude.

\section{UNDERSTANDING THE MEANING OF PLURALITY AND PLURALIST ATTITUTE}

In social studies, diversity could be a cohesive factor between different groups, and could also be a factor that causes conflict (Al Qadrie, 2002: 163; Barth, 1988; Haitami et al., 2007: 2). Diversity will be a unifying as long as it is 
managed into harmony, without having to force uniformity. However, if these differences cannot be managed properly, it will be become a factor triggers conflict between different groups (Moh. Haitami Salim, 2012).

From a religious perspective, diversity is the inevitability which is impossible to reject because it is part of the permanent way of Allah. Thus, diversity itself is predestined by Allah with the intent as a test to the degree of human faith and gratitude for the gifts given by Him by turning diversity a competitive capital. In addition, the inevitability of diversity is also a medium for people to study social life so they will get to know one another. This is simply because no human being is perfect, hence the existence of others becomes sine qua non. Nurcholis Madjid (2000: 159) argued that no society is exactly singular, and one exists, according to the Qur'an, it merely exists on the surface and hides the "divided hearts" (Qur'an Al-Hashr (59): 14).

The development of science and technology has turned the world into a global village which then results in heterogeneity at the corners of the world, in terms of economic, cultural, ethnic, racial, religious differences. This reality, on the one hand, may encourage interaction, cooperation, accommodation and acculturation between various community groups, but on the other hand, can give rise to tensions and even conflicts between them, because each group at the same time will attempt to preserve its identity, including ideological views on religion (M. Atho Mudzhar in Moh. Soleh Isre, 2003:1).

Conceptually, there is primordial plurality (taken for granted) and there is also plurality that arises as the logical consequence of pragmatic choices. Primordial plurality is the difference which is already predestined Allah upon His creatures. No one can deny the fact of differences such as race, members of certain ethnic groups, nations and, to a certain degree, religions (being plural, religion is taken as a legacy not through conscious and rational choice). Meanwhile, pragmatic plurality is the differences that arise later as a consequence of differences in the point of view, interest and group affiliation. When the two come together, the common sense that differences are inevitable will begin to collapse, and then various attempts will be made to exploit the issues of primordiality, such as religion, ethnicity and race, as an instrument to justify certain pragmatic interests (Moh. Haitami Salim, 2012).

To avoid misinterpretation, this article needs to define the meaning of pluralist attitude. According to the Dictionary of the Indonesian Language (Ministry of National Education, 2011), attitude is defined as way doing things based on the formation of opinion or belief, while the word pluralist is derived from the word plural which means diverse (http://id.wikipedia.org/wiki/Pluralistme, accessed July 1,2013). So the pluralist attitude in this article is the attitude of 
accepting and appreciating differences as the reality of life, both in religion and in the life of a nation. This attitude grows from a basic awareness that besides ourselves there are others who are basically not the same as we are, because of different religions, way of thinking, ethnicity, social status, economic status etc. It is an affirmation of faith plurality is real evidence of the nature of the Supreme Power of Allah.

\section{PHILOSOPHICAL VIEW OF ISLAM ON PLURALITY}

Islam as a religion that I (we) believe to have given the number of philosophical guidance, found both in several verses of the Quran and the Hadith. The first philosophical view; the most fundamental reminder that we, human beings, came from the same origin and type, as Allah said in Surah Ar-Rum (30): 20: "And of His signs is that He created you from dust; then, suddenly you were human beings dispersing (throughout the earth)". Also in Surah An-Nisa ' (4):1 Allah said, "O mankind, fear your Lord, who created you from one soul and created from it its mate and dispersed from both of them many men and women." Then in Surah Al-Hujurat: 13 "O mankind, indeed We have created you from male and female and made you peoples and tribes that you may know one another. Indeed, the most noble of you in the sight of Allah is the most righteous of you." This view will bring awareness to us that all human beings should realize that they are brothers and sisters as they are descended from the same origins.

The second philosophical view; with respect to diversity of ethnicity, skin color and language. In Surah Al-Hujurat: 13 above, it is clearly stated that: “. .. and made you peoples and tribes .... In Surah Ar-Rum (30): 22 it is explained: “ And of His signs is the creation of the heavens and the earth and the diversity of your languages and your colors .... The awareness built through the second philosophical view is that plurality is the grace, the power and the will of Allah Almighty, the Creator. It is more assured in other verses as in Surah AlMaidah (5): 48 which goes: "Had Allah willed, He would have made you one nation [united in religion], but [He intended] to test you in what He has given you; so race to [all that is] good ... ". Similarly, in the Hud (11): 118, " And if your Lord had willed, He could have made mankind one community; but they will not cease to differ."

The third philosophical view; the plurality of Allah's creation has positive potential inherent in the sense of the uniting factor, and the negative potential in the sense of the dividing factor. The potential contained in the above verses is to know one another (QS. Al-Hujurat: 13), to race to [all that is] good (QS. Al-Maidah (5): 48) and to have disagreement (Q.S. Hud (11): 118). On which 
potential man sees plurality will depend on his understanding of the plurality itself and the tendency of his choice.

The fourth philosophical view; the nobleness of a human being in the sight of Allah is not determined by the tribe, nation, differences of language and skin colors, but by the level of devotion to Allah. In addition to the above verses (QS. Al-Hujurat:13; Al-Maidah:48), it is also emphasized in the Hadith of the Prophet which goes "There is no superiority of an Arab over a non-Arab except in whoever fears Allah the most."

The four philosophical views have indeed undermined the feelings of superiority of ethnicity, race, descent or religion. The Islamic values, as indicated above, are not merely normative, but have become empirical exemplified by Prophet Muhammad in the community of Medina and then manifested in the Declaration of the Charter of Medina (Moh. Haitami Salim, 2012 (a): 27-29).

\section{THE IMPORTANCE OF INSTILLING THE PLURALIST ATTITUDE IN ISLAMIC EDUCATION}

As discussed above, that the plurality of a nation is a reality and even has become the will of Allah Almighty. Therefore, the pluralist attitude is also an inevitability. This attitude is not something that can appear automatically, but has to go through the process of understanding, coaching, guidance and training and education. Similarly, it has been said previously that effective coaching to build a good and true pluralist attitude is through a formal education process in schools or madrasahs since the formal educational process is carried out in a systematic, planned, controlled way and has adequate supporting facilities.

Among the subjects relevant for establishing such attitude is the instruction of Islamic education. The relevance of the cultivation of the pluralist attitude in the Islamic education learning can start from the objectives of the education itself, the content of learning materials and strategies, and the methodology that is able to develop the attitude. In addition, the sources of books selected and the instructional media used also serve as an important factor. With regard to the 2013 curriculum that emphasizes on nationalism-based character education, the subject of Islamic education is highly relevant to serve as one of the means to build the pluralist attitude, either in schools or madrasahs in each level of education. Thus the urgency to build the pluralist attitude through the learning of Islamic religious education in schools and madrasah becomes very significant. 


\section{INSTRUMENTS NEEDED TO ESTABLISH A PLURALIST ATTITUDE IN ISLAMIC EDUCATION}

The instruments that need to be prepared in an attempt to instill the pluralist attitude through the instruction of Islamic education at school and madrasah, are as follows:

1. The availability of educators who understand the learning objectives of Islamic education as set forth in the 2013curriculum;

2. Lesson plans that are relevant to the character that will be built with regard to the pluralist attitude;

3. The implementation of a learning process that is in accordance with the required instructional steps;

4. The development of learning materials in the context of the plurality of the nation;

5. The availability of the books and instructional media that are relevant to the character of the pluralist attitude to be built;

6. The availability of instruction evaluation tools that emphasize on attitude (affective domain).

All of the above instruments should be understood by every educator and carried out in accordance with the lesson plans formulated.

\section{CLOSING REMARKS}

The fact that Indonesia is a plural and multicultural nation should be addressed wisely by its people. Otherwise, the plurality will bring great disaster for the country and the people, as it could potentially become a dividing factor that undermines unity the nation. Therefore, the pluralist attitude should be taught to the children of this nation since their early childhood. The pluralist attitude will be effective if it is built through a process of formal education in schools and madrasahs in each subject, particularly the Islamic education.

The 2013 curriculum that emphasizes on character education with nationalism insights is possible to build the pluralist attitude. In addition, it has also provided significant room for the development of instruction, especially on subject of Islamic education and civics education. In this context, the teachers as educators have very important duties and responsibilities to carefully and precisely prepare the lesson plans, learning materials that are relevant to the life of plural society, as well as to choose strategies and appropriate learning methods that promote the pluralist attitude, using sources and learning media that support the purpose of the lesson, performing the steps of learning consistently, and conducting the assessment with an emphasis on the affective domain. To carry out all the responsibilities effectively, teachers as educators 
should be able understand their professional duties. Therefore, hopefully, efforts to increase teachers' professionalism should be made by various parties continuously.

\section{BIBLIOGRAPHY}

Barth, Fredrik (ed). 1988. Kelompok Etnik dan Batasannya. Jakarta: UI Press..

Departemen Pendidikan Nasional, 2011 Kamus Besar Bahasa Indonesia. Jakarta: Gramedia Pustaka Utama.

Gaus AF, Ahmad. 2006. Kekaisan Nurchalish Madjid dan Dinasti-Dinasti Pluralisme Islam Kontemporer dalam Menembus Batas Tradisi: Menuju Masa Depan yang Membebaskan. Jakarta: Universitas Paramadina dan Kompas.

Salim, Moh. Haitami, 2009. Pluralisme: Suatu Tinjauan Fakta Sosial. Makalah disampaikan pada Seminar Naasional Membincang Pluralisme Perspektif agama, sosial dan budaya, diselenggarakan oleh P3M STAIN Pontianak, pada Sabtu, 16 Mei 2009 di Pontianak. tt. 2012 (a). Ikhtiar Membangun Kalimantan Barat yang Maju dan Bermartabat, STAIN Press. Pontianak 2012 (b). Mempererat Kerukunan Etnis dan Umat Beragama dalam Tatanan Masyarakat Pluralis-Multikultur di Kalimantan Barat, Bulan Sabit Press-Pontianak 2012 (c). Pembauran Bangsa Dengan Penguatan Empat Pilar Kebangsaan Dengan Mensinergikan Peran Tri Pusat Pendidikan, Makalah Diskusi disampaikan dalam Diskusi Pembauran Kebangsaan Pemerintah Kota Pontianak, 31 Oktober 2012. tt.

, dkk. 2012, Mengukuhkan Kerukunan Umat Beragama di Kalimantan Barat. Kerjasama FKUB Kalbar, CAIREU STAIN Pontianak, Kanwil Kementerian Agama Kalbar dan Forum Peduli Ibu Pertiwi (FPIP) Kalbar-Pontianak.

Salim, Moh. Haitami, Eka Hendry, Dulhadi, 2007. Prasangka Antar Kelompok Etnis di Kalimantan Barat. Pontianak: STAIN Press.

Al-Qadrie, Syarief I. 2002. Factors in Ethnic Conflict, Ethnic Edentity and Consciousness, and the Indications of Disintegrative. Dalam Chaedir S. Bamualim dkk. (ed). Communal Conflicts In Contemporary Indonesia. Konrad Adenoauer Stiftung dan Center for Language and Culture. Jakarta.

Taher, Tarmizi, 1998. Menuju Ummatan Wasathan. Jakarta: Pusat Pengkajian Islam dan Masyarakat (PPIM)-IAIN Jakarta.

http://id.wikipedia.org/wiki/Pluralisme, akses 1 Juli 2013 